ARTIKEL PENELITIAN

\title{
PENGARUH INFEKSI CACING USUS TERHADAP EKSPRESI INTERFERON GAMMA SERUM PASKA PEMBERIAN IMUNISASI TETANUS TOKSOID
}

\author{
Selfi Renita Rusjdi ${ }^{1}$, Hafni Bachtiar ${ }^{2}$, Nuzulia Irawati $^{3}$ \\ 1. Bagian Parasitologi Fakultas Kedokteran Universitas Andalas \\ 2. Bagian Ilmu Kesehatan Masyarakat Fakultas Kedokteran Universitas Andalas \\ 3. Bagian Parasitologi Fakultas Kedokteran Universitas Andalas \\ email : drselfirenita_rusjdi@yahoo.co.id
}

\section{Abstrak}

Penyakit cacing usus masih merupakan masalah kesehatan di Indonesia. Penyakit ini mempunyai dampak merugikan pada manusia terutama pada anak. Selain menimbulkan gangguan gizi, cacing ini juga menimbulkan penurunan respon terhadap antigen. Penurunan respon ini terjadi akibat respon polarisasi Th2 pada infeksi cacing usus. Tetanus toksoid yang diberikan dalam Bulan Imunisasi Anak Sekolah merupakan antigen sebagai penginduksi respon sel $T$. Penelitian ini bertujuan untuk mengetahui pengaruh infeksi cacing usus terhadap ekspresi IFN- $\gamma$ serum paska pemberian tetanus toksoid.

Lokasi penelitian dilakukan di Kecamatan Batang Anai Padang Pariaman dengan menggunakan rancangan potong lintang. Populasi dalam penelitian ini adalah murid kelas 2 dan kelas 3 SDN 08 dan SDN 22 Batang Anai Padang Pariaman. Status kecacingan didapatkan dari pemeriksaan feses metoda Kato-Katz. Kadar IFN- $\gamma$ serum didapatkan dari pemeriksaan serum metode ELISA. Pengolahan dan analisa data menggunakan uji Kolmogorov-Smirnov.

Hasil penelitian pada kelompok yang terinfeksi cacing usus didapatkan rerata kadar IFN- $\gamma$ adalah sebesar $0,15 \pm 0,16 \mathrm{pg} / \mathrm{ml}$ dan kelompok kontrol didapatkan sebesar 1,4 $\pm 1,02 \mathrm{pg} / \mathrm{ml}$. Terdapat perbedaan bermakna kadar IFN- $\gamma$ antara kelompok yang terinfeksi cacing usus dengan kelompok kontrol. $(\mathrm{p}<0,05)$.

Dari hasil penelitian dapat disimpulkan bahwa infeksi cacing usus dapat menekan ekspresi IFN- $\gamma$ terhadap pemberian tetanus toksoid.

Kata kunci: Cacing Usus, Tetanus Toksoid, Interferon gamma (IFN- $\gamma)$

\section{Abstract}

Intestinal helminthiasis is still unsolved problem in Indonesia. Children are particularly vulnerable to get health problem caused by those infection. The health problems are malnutrition and nowadays impairment immune response of antigen. The impairment is caused by Th2 polarized response. Tetanus toksoid which is annually given to elementary school children in Bulan Imunisasi Anak Sekolah is 
known as $\mathrm{T}$ cell strong inducer after vaccination. The aim of this study was to determine the influence of intestinal helminthiasis on serum IFN- $\gamma$ expression after administered tetanus vaccination.

This research is cross sectional study and it was conducted in Kecamatan Batang Anai Padang Pariaman. Population of this study are $2^{\text {nd }}$ and $3{ }^{\text {rd }}$ grade of elementary school student in SDN 08 and SDN 22. Intestinal helminthiasis status was taken by Kato - Katz methode of fecal examination. Serum IFN- $\gamma$ was analyzed by ELISA methode. The data was analyzed by Kolmogorov-Smirnov test.

Mean of serum IFN- $\gamma$ in intestinal helminthiasis group are $0,15 \pm 0,16 \mathrm{pg} / \mathrm{ml}$ and uninfected control group are 1,4 $\pm 1,02 \mathrm{pg} / \mathrm{ml}$. There was significant difference on serum IFN- $\gamma$ level in intestinal helminthiasis group and uninfected control group $(\mathrm{p}<0,05)$.

This study concluded that intestinal helminthiasis may impair serum IFN- $\gamma$ expression to tetanus vaccination.

Key word: intestinal helminthiasis, tetanus toxoid, interferon gamma (IFN- $\gamma)$ 


\section{Pendahuluan}

Penyakit cacing usus terutama yang ditularkan melalui tanah masih merupakan masalah kesehatan di beberapa negara berkembang termasuk Indonesia. Prevalensi penyakit kecacingan ini masih cukup tinggi terutama pada kelompok masyarakat dengan higienisitas dan sanitasi yang rendah. ${ }^{(1,2)}$ Prevalensi penyakit cacing usus di Indonesia adalah 60\%. Dari angka prevalensi $60 \%$ itu, $21 \%$ diantaranya menyerang anak usia Sekolah Dasar. Penelitian yang dilakukan oleh Alwi (2008) di Sekolah Dasar kabupaten Padang Pariaman didapatkan kejadian infeksi yang cukup tinggi dengan prevalensi mencapai $85 \%$. $^{(3-4)}$

Penyakit cacing usus ini sering terjadi tanpa gejala sehingga sering dianggap sebagai penyakit yang tidak berbahaya. Pada kenyataannya, penyakit cacing usus ini mempunyai banyak dampak yang merugikan pada manusia terutama pada anak yang merupakan kelompok masyarakat yang mempunyai frekuensi terbanyak menderita kecacingan. Selain menimbulkan gangguan gizi dan gangguan pertumbuhan, cacing ini juga dapat menimbulkan perubahan respon imun. Beberapa penelitian mengenai perubahan respon imun ini telah banyak dilakukan. ${ }^{(1,5)}$ Telah diketahui dari penelitian para ahli bahwa infeksi akut cacing usus menimbulkan perubahan keseimbangan $\mathrm{T}$ helper1/T helper2 (Th1/Th2) ke arah sel Th2 (Th2 polarized). Polarisasi respon imun ke arah sel Th2 ini ditandai dengan peningkatan Th2 specific cyokines seperti interleukin 4 (IL-4), interleukin 5 (IL-5), interleukin 13 (IL-13) dan peningkatan imunoglobulin E (IgE). ${ }^{(6-7)}$ Yazdanbakhs (2001) juga mendapatkan bahwa infeksi cacing usus akan menginduksi respon sel Th2 dan secara tidak langsung akan menekan sel Th1 karena sifat sel T helper yang saling menekan (downregulate) satu sama lain. ${ }^{(8)}$

Penekanan respon sel Th1 ini juga terjadi pada infeksi cacing kronis. Pada infeksi kronis terjadi modified Th2 response yang tidak hanya menimbulkan penekanan pada Th1 tetapi juga menimbulkan cellular hyporesponsive secara umum. ${ }^{(9)}$

Erb (2002) dan McKee (2004) memperlihatkan bahwa pada hewan coba yang diinfeksi oleh cacing akan mengalami hiporesponsif sel Th1. ${ }^{(10-11)}$ Salah satu cara untuk mengetahui penurunan aktifitas sel Th1 pada infeksi cacing ini adalah dengan melihat adanya penekanan produksi IFN- $\gamma$ yang merupakan Thl specific cytokines. ${ }^{(12-}$ 15)

Pemberian imunisasi tetanus toksoid terhadap anak sekolah merupakan salah satu upaya strategis pemerintah dalam program imunisasi untuk mencegah penyakit tetanus. Program imunisasi tetanus toksoid ini dilaksanakan sejak tahun 1998 dalam kegiatan Bulan Imunisasi Anak Sekolah (BIAS). Kegiatan ini dilakukan satu kali setahun oleh dinas kesehatan bekerja sama dengan pihak puskesmas. ${ }^{(16)}$ Tetanus toxoid yang diberikan ini merupakan suatu imunogen yang dikenal sangat poten untuk menginduksi respon sel T. Mayer (2002) dan Bishop (2005) telah meneliti respon imun paska pemberian tetanus toksoid dengan menilai secara kuantitatif kadar IFN- $\gamma$ dan antibodi antitoksin. Beberapa penelitian mengenai respon sel Th1 pada infeksi cacing terhadap tetanus toxoid telah mulai dilakukan. Pada penelitian yang dilakukan di India didapatkan 
bahwa respon IFN- $\gamma$ terhadap imunisasi tetanus toxoid pada penderita filariasis lebih lemah dibandingkan dengan kelompok kontrol. Hasil yang sama juga didapatkan pada penderita onchocerciasis di Equador. ${ }^{(17-20)}$

\section{TUJUAN PENELITIAN}

Mengetahui perbedaan kadar IFN$\gamma$ pada anak yang terinfeksi cacing usus dengan anak yang tidak terinfeksi cacing usus paska pemberian tetanus toksoid.

\section{BAHAN DAN CARA}

Penelitian ini dilakukan pada murid Sekolah Dasar Negeri 08 dan 22 Kecamatan Batang Anai Kabupaten Padang Pariaman. Subyek penelitian adalah murid kelas 2 dan 3 dengan status gizi baik dan berbadan sehat. Pemeriksaan tinja dilakukan secara mikroskopik dengan metode Kato Katz. Pengambilan darah, penimbangan berat badan dan pegukuran tinggi badan dilakukan di Puskesmas Ketaping Kabupaten Padang Pariaman. Untuk menentukan derajat status gizi murid digunakan parameter Berat menurut Tinggi Badan yang dibandingkan dengan Baku (median) NCHS WHO Geneva 1983 menurut umur dan jenis kelamin. Pada penelitian ini status gizi baik dan lebih dikelompokkan sebagai gizi baik. Proses Pemeriksaan kadar interferon gamma serum dilakukan dengan cara ELISA di laboratorium Patologi Klinik RS M.Djamil Padang. Izin subyek penelitian dilakukan dengan mengisi formulir pernyataan persetujuan yang diberikan oleh peneliti dan ditandatangani oleh orang tua subyek. Analisa data dilakukan dengan uji untuk dua sampel bebas Kolmogorov - Smirnov.

\section{HASIL PENELITIAN}

Selama penelitian ini berlangsung diperoleh sampel sebanyak 61 murid Sekolah Dasar kelas 2 dan 3 dari SD Negeri 08 dan SD Negeri 22 Kecamatan Batang Anai Kabupaten Padang Pariaman. Murid SD pria yang menjadi sampel lebih banyak yaitu 36 orang (59\%) sedangkan wanita 25 orang (41\%). Dari 61 murid Sekolah Dasar yang diperiksa didapatkan murid yang tidak terinfeksi cacing usus lebih banyak yaitu 34 orang $(55,74 \%)$ sedangkan murid yang terinfeksi cacing usus 27 orang $(44,26 \%)$.

Tabel 1. Distribusi infeksi cacing usus berdasarkan spesies cacing pada murid Sekolah Dasar

\begin{tabular}{ccc}
\hline $\begin{array}{c}\text { Status Infeksi } \\
\text { Cacing Usus }\end{array}$ & $\begin{array}{c}\text { Jum- } \\
\text { lah }\end{array}$ & Persentase \\
\hline Infeksi Tunggal & & \\
$\quad \begin{array}{c}\text { Ascaris } \\
\text { lumbricoid } \\
\text { es }(\mathrm{Al})\end{array}$ & 3 & 11,1 \\
Trichuris & 1 & 3,7 \\
trichiura & & \\
(Tt) & & \\
Cacing & 0 & 0 \\
tambang & & \\
Infeksi Multipel & & \\
Al $+\mathrm{Tt}$ & 11 & 40,7 \\
$\mathrm{Al}+\mathrm{Ct}$ & 1 & 3,7 \\
$\mathrm{Tt}+\mathrm{Ct}$ & 2 & 7,4 \\
$\mathrm{Al}+\mathrm{Tt}+$ & 9 & 33,3 \\
$\mathrm{Ct} \quad$ & & \\
\hline Jumlah & 27 & 100 \\
\hline
\end{tabular}

Ket: $\quad \mathrm{Al}+\mathrm{Tt}=$ Ascaris lumbricoides + Trichuris trichiura

$\mathrm{Al}+\mathrm{Ct}=$ Ascaris lumbricoides + Cacing Tambang

$\mathrm{Tt}+\mathrm{Ct}=$ Trichuris trichiura + Cacing Tambang

$$
\begin{aligned}
\mathrm{Al}+\mathrm{Tt}+\mathrm{Ct}= & \text { Ascaris lumbricoides } \\
& + \text { Trichuris trichiura } \\
& + \text { Cacing Tambang }
\end{aligned}
$$


Murid Sekolah Dasar yang terinfeksi cacing usus ini terdiri dari infeksi tunggal dan infeksi multiple. Prevalensi infeksi tunggal terbanyak adalah infeksi oleh Ascaris lumbricoides $(11,1 \%)$. Infeksi multipel terbanyak adalah Ascaris lumbricoides dan Trichuris trichiura $(40,7 \%)$

Tabel 2. Kadar IFN- $\gamma$ Paska Pemberian Imunisasi Tetanus Toksoid berdasarkan Status Infeksi Cacing Usus

\begin{tabular}{ccc}
\hline $\begin{array}{c}\text { Status Infeksi } \\
\text { Cacing Usus }\end{array}$ & $\begin{array}{c}\text { IFN- } \gamma(\mathrm{pg} / \mathrm{ml}) \\
(\text { Mean } \pm \text { SD) }\end{array}$ & $\mathrm{P}$ \\
\hline Cacing Usus (+) & $0,15 \pm 0,16$ & 0,020 \\
Cacing Usus (-) & $1,4 \pm 1,02$ & \\
\hline
\end{tabular}

Rerata kadar IFN- $\gamma$ pada anak yang tidak terinfeksi cacing usus $(1,4 \pm$ $1,02)$ lebih tinggi dibandingkan dengan anak yang terinfeksi cacing usus $(0,15 \pm$ $0,16)$. Berdasarkan uji statistik terdapat perbedaan bermakna kadar IFN- $\gamma$ antara anak yang terinfeksi cacing usus dengan anak yang tidak terinfeksi cacing usus $(\mathrm{p}<0,05)$.

\section{PEMBAHASAN}

Hasil penelitian yang didapatkan pada penelitian ini menunjukkan bahwa terdapat perbedaan bermakna kadar IFN$\gamma$ antara anak yang terinfeksi cacing usus dengan anak yang tidak terinfeksi cacing usus. Kelompok kontrol yang tidak terinfeksi cacing usus mempunyai kadar IFN- $\gamma$ yang lebih tinggi dibandingkan dengan kelompok yang terinfeksi cacing usus. Sebagai perbandingan, kadar IFN- $\gamma$ pada kedua kelompok penelitian ini tetap lebih tinggi dari anak yang tidak diberi intervensi (imunisasi tetanus toksoid) yang mempunyai rerata kadar IFN- $\gamma$
$0,042 \pm 0,03$. Pada penelitian ini tetanus toksoid berperan sebagai antigen yang akan menstimulasi respon sel $\mathrm{T}$ khususnya IFN- $\gamma .{ }^{(15,17-18)}$

Yazdanbakhsh (2001) dan Maizels (2003) mendapatkan bahwa penekanan aktifitas Th1 terhadap masuknya antigen yang terjadi akibat infeksi cacing, berlaku bagi related antigen (antigen dari cacing itu sendiri) maupun unrelated antigen (selain antigen cacing). Unrelated antigen bersifat sangat umum, dapat berasal dari infeksi alamiah, vaksin maupun antigen dari organ yang ditransplantasikan. ${ }^{(8-9)}$

Penekanan respon sel Th1 pada infeksi cacing juga ditemukan pada penelitian yang dilakukan secara eksperimental oleh Erb (2002) dan McKee (2004) memperlihatkan bahwa pada hewan coba yang terinfeksi cacing akan mengalami hiporesponsif sel Th1 setelah stimulasi oleh suatu antigen. ${ }^{(10-11)}$ Salah satu cara untuk mengetahui penurunan aktifitas sel Th1 pada infeksi cacing ini adalah dengan melihat adanya penekanan produksi IFN- $\gamma$ yang merupakan Th1 specific cytokines. ${ }^{(12-15)}$ Sabin (1996) mendapatkan hasil yang sama dengan penelitian ini. Sabin melakukan penelitian pada orang yang terinfeksi cacing Schistosoma mansoni yang diberi imunisasi tetanus toksoid. Hasil penelitian menunjukkan bahwa kelompok orang yang terinfeksi cacing mempunyai kadar IFN- $\gamma$ yang lebih rendah (atau bahkan tidak teukur) dibandingkan dengan kelompok kontrol. Kadar IFN- $\gamma$ yang didapatkan ini mempunyai hubungan terbalik dengan intensitas atau derajat infeksi cacing Schistosoma mansoni. Dari penelitian yang dilakukan oleh Sabin (1996) juga didapatkan bahwa pada kelompok yang terinfeksi cacing terjadi Th2 polarized 
response, sedangkan kelompok kontrol mengalami Th1 polarized reponse atau ThO like response. ${ }^{(21)}$ Dari hasil ini juga diperkirakan bahwa infeksi oleh cacing ini akan meningkatkan suseptibilitas individu terhadap infeksi di kemudian hari dan menurunkan efektitifitas vaksin.

Pada penelitian yang dilakukan Nookala (2004) di India didapatkan bahwa respon IFN- $\gamma$ terhadap imunisasi tetanus toxoid pada penderita filariasis lebih lemah dibandingkan dengan kelompok kontrol. ${ }^{(20)}$

Dari beberapa penelitian yang dilakukan oleh para ahli, telah banyak diperoleh kesimpulan yang sama dengan hasil penelitian ini. Para ahli ini menemukan bahwa cacing nematoda intestinal pada hewan coba maupun manusia akan mempengaruhi respon imun secara umum baik seluler maupun humoral. Kejadian ini dibuktikan dengan intervensi berupa pemberian anti helmintik yang memberikan perbaikan respon imun spesifik terhadap toksin tetanus, difteri maupun kolera. Hasil ini mengindikasikan bahwa program eradikasi infeksi cacing akan mempengaruhi angka kejadian infeksi bakteri dan virus. ${ }^{(22-23)}$

Fenomena penurunan respon terhadap vaksin ini dapat dijelaskan dari studi yang dilakukan oleh Maizel (2003). Peneliti tersebut mengemukakan bahwa pada infeksi cacing akut terjadi Th2 polarized response yang mengakibatkan penekanan aktifitas sel Th1 melalui sitokin yang dihasilkannya. Pada kasus infeksi cacing kronis, penekanan Th1 tidak lagi diakibatkan oleh aktifitas Th2 tetapi diakibatkan oleh aktifitas Treg yang menimbulkan cellular hyporeponsive secara umum. ${ }^{(9)}$
Penelitian yang dilakukan di Gabon oleh Riet et al. (2008) mendapatkan hasil yang berbeda dengan teori yang telah dikemukakan sebelumnya. Beliau mendapatkan bahwa tidak terdapat perbedaan yang nyata pada respon seluler dan humoral setelah pemberian tetanus toksoid pada penduduk yang terinfeksi cacing usus dan cacing Schistosoma haemotobium. Penelitian ini juga membantah hasil penelitian terdahulu dimana tidak terdapat perbedaan respon imun paska imunisasi antara anak dengan status nutrisi baik dengan anak malnutrisi. Hasil ini menimbulkan pemikiran bahwa terdapat terdapat banyak faktor yang mempengaruhi respon paska imunisasi. Menurut Riet et al. (2008) faktor - faktor yang berkemungkinan mempengaruhi adalah spesies cacing yang menginfeksi dan status infeksi malaria. ${ }^{(24)}$

\section{KESIMPULAN}

Terdapat perbedaan kadar IFN- $\gamma$ pada anak yang terinfeksi cacing usus dengan anak yang tidak terinfeksi cacing usus paska pemberian tetanus toksoid.

\section{SARAN}

1. Perlu penelitian untuk mengetahui kadar Thl scpecific cytokines lainnya paska stimulasi antigen pada penderita infeksi cacing usus.

2. Perlu penelitian isolasi limfosit terutama Th1 pada penderita infeksi cacing usus untuk melihat respon sel terhadap stimulasi tetanus toksoid in vivo maupun ex vivo.

3. Perlu penelitian lebih lanjut untuk melihat efektifitas berbagai vaksin 
pada penderita infeksi cacing usus.

\section{KEPUSTAKAAN}

1. Dewayani RB. Albendazole pada Soil Transmitted Helminth. Bagian Ilmu Kesehatan Anak Fakultas Kedokteran Universitas Sumatera Utara. E-USU Repository. Universitas Sumatera Utara; 2004.

2. Elmi. Status Gizi dan Infestasi Cacing Usus pada Anak Sekolah Dasar. Bagian Ilmu Kesehatan Anak Fakultas Kedokteran Universitas Sumatera Utara. EUSU Repository. Universitas Sumatera Utara; 2004.

3. Departemen Kesehatan, 2008. 60\% Penduduk Indonesia Cacingan, Kerugian Capai 0,5 T. Pusat Data dan Informasi Perhimpunan Rumah Sakit Seluruh Indonesia. Jakarta.

4. Alwi A. Nematoda Usus yang Penularannya melalui Tanah pada Murid Sekolah Dasar di Kecamatan Lubuk Alung dan Barang Anai. Thesis, Universitas Andalas, Padang; 2008.

5. Jankovic D, Steinfelder S, Kullberg MC, Sher A, Bethesda Md. Mechanisms Underlying Helminth-Induced Th2 Polarization: Default, Negative or Positive Pathways? In Parasite and Allergy. Karger AG. Switzerland; 2006.

6. Fallon PG, Mangan NE. Suppression of the Th2-type allergic reaction by helminth infection. Nature Review Immunology March 2007; vol 7 : 220-230

7. Hartgers FC, Obeng BB, Boakye $\mathrm{D}$, Yazdanbakhsh M. Immune Response during Helminth Malaria Co-Infection: A Pilot Study in Ghanian School Children. Journal of Parasitology 2008; 135: 855-890

8. Yazdanbakhsh M, Biggelaar A, Maizels RM. Th2 Responses without Atopy: Immunoregulation in Chronic Helminth Infection and Reduced Allergic Disease. Trends in Immunology 2001; 22: 372377.

9. Maizels RM, Yazdanbakhsh. Immune Regulation by Helminth Parasites. Cellular and Molecular Mechanism. Nature Review 2003; 3: 733-744.

10. Erb, JK, Trujilo C, Fugate M, Moll H. Infection with Helminth Nippostrongylus braziliensis does not Interfere with Efficient Elimination of Mycobacterium bovis BCG from the Lungs of Mice. Clinical and Diagnostic Laboratory Immunology 2002; 9(30): 727-730.

11. McKee SA, Pearce JE. CD25+ dan CD4+ Contribute to Th2 Polarization during Helminth Infection by Suppressing Th1 Response Development. The Journal of Immunology 2004; 173: 1224-1231. 
12. Montenegro S, Abath F, Domingies, Melo W, Morais C, Coutinho E, Mahanty S. Preliminary Results on the Effect of $\mathrm{CD} 40 / \mathrm{CD} 40 \mathrm{~L}$ Interaction and SAC-Induction on IFN gamma Expression in Human Schistosomiasis. Memorias do Instituto Oswaldo Cruz 2001; 96 (1): 103-105.

13. Elias D. Helminth and Immunity against Tuberculosis. Karolinska University Press. Stockholm, Sweeden; 2006.

14. Graham AL. Ecological rules Governing HelminthMicroparasite Infection. In Institutes of Evolution, Immunology and Infection Research. University of Edinburg. PNAS Januari 2008; 105 (2): 566570.

15. Kholoussi SM, Bayoumi FS, ElNady H. Estimation of Serum Interferon-Gamma Level in Childhood Acute Lymphoblastic Leukemia Patients. Journal of Medical Science 2008: 8 (1): 6872.

16. Isbagia WD, Handayani S, Siburian F, Sumarno. Pengaruh Status Imunisasi Difteri Pertusis dan Tetanus terhadap Respon Kekebalan Difteri dan Tetanus padsa Murid Kelas I Sekolah Dasar di Kecamatan Cimandala. Buletin Penelitian Kesehatan 2004; 32 (2): 62-72.
17. Mayer S, Laumer M, Mackensen A, Andreesen R, Krause SW. Analysis of the Immune Response against Tetanus Toxoid: Enumeration of Specific T Helper Cell by The Elispot Assay. Journal of Immnunobiology 2002; 205: 282-289.

18. Bishop NC, Walker GJ, Bowley LA, Evans KF, Molyneux K, Wallace FA, Smith AC. Lymphocyte Response to Influenza and Tetanus Toxoid in vitro Following Intensive Exercise and Carbohydrate Ingestion on Consecutive Days. Journal Appl Physiol 2005; 10: 1152.

19. Cooper JP, Espinel I, Wieseman M, Paredes W, Espinel M, Guderian HR, Nutman BT. Human Onchocerciasis and Tetanus Vaccination: Impact on the Postvaccination Antitetanus Antibody Response. Infection and Immunity 1999; 67 (11): 5951-5957.

20. Nookala S, Srinivasan, Kaliraj P, Narayanan BR, Nutman BT. Impairment of Tetanus-Specific Cellular and Humoral Response following Tetanus Vaccination in Human Lymphatic Filariasis. Infection and Immunity 2004; 72 (5), 2598-2604.

21. Sabin EA, Araujo MI, Carvalho EM, Pearce EJ. Impairment of tetanus specific Th1-like immune response in human infected with Schistosoma mansoni. Journal of 
Infectious Disease 1996; 173(I), $269-272$.

22. Mulcahy G, O’Neil, Donnely S, Dalton JP. Helminth at Mucosal Barriers - Interaction with the Immune System. Advanced Drug Delivery Reviews. 2004; 56: 853868.

23. Urban JF, Steenhard NR, SolanoAguilara GI, Dawsona HD, Iwealac OI, Naglerc CR, Nolandd GS, Kumard N, Anthonye RM, Shea-Donohuef T, Weinstockg J, Gauseh WC. Infection with parasitic nematodes confounds vaccination efficacy. Journal of Veterinary Parasitology August 19 2007; 148(1): 14-20.
24. Riet EV, Retra K, Adegnika A, Jol-van der Zijde, Uh H-W, Lel B, Issifou $\mathrm{S}$, Kremsner PG, Maydanbakhsh M, van Tol MJD, Hartgers FC, 2008. Cellular and humoral responses to tetanus vaccination in Gabonese. Vaccine 2008; 26: 3690-3695 